\title{
ТУБЕРКУЛОЗА НА УРОГЕНИТАЛНАТА СИСТЕМА
}

\author{
Христо Димитров \\ Отделение по хемодиализа \\ МБАЛ-Бургас
}

\section{ЧЕСТОТА НА УРОГЕНИТАЛНАТА ТУБЕРКУЛОЗА (УГ ТБК)}

ТБК на урогениталната система заема първо място след белодробната форма на туберкулоза (1). До включването на противотуберкулозни средства честотата на болестта варира до 20\% в урологичните отделения. Днес годишно умират 2 милиона болни по целия свят (2).

\section{Етиология}

Микобактериите се числят към семейството на микобактериацеа. Те са киселинноустойчиви патогени, с напречен размер 0,2-0,5 микрона и дължина 1-5 микрона. В по-стари среди образуват разклонения, растат аеробно върху глицерин или синтетични среди. Има студенокръвни и топлокръвни патогени. Mycobacterium bovis причинява говеждата туберкулоза. Патогенен е за хората, свинете и зайците (7). Доказва се, че депонирането на ТБК в бъбреците е поради нарушена микроциркулация чрез емболизация на малките артерии. Първичното инфилтриране на ТБК бацилите в бъбречната кора е израз на строго аеробните свойства на причинителя. Парциалното налягане на кислорода в белите дробове е $140 \mathrm{~mm} \mathrm{Hg}$, а в бъбреците около 130-120 mm $\mathrm{Hg}$, което обяснява тази локализация $(1,2)$. Високовирулентните щамове навлизат в макрофагите, размножават се там и нахлуват в кръвообращението. За кратко време водят до язвен папилит. Макроорганизмът има висока резистентност към ТБК, затова болестта често протича латентно. Съобщава се, че кавказката и монголската раса имат вроден имунитет срещу ТБК (3). Фактори, отключващи болестта, са гладуване, захарен диабет, имуносупресори (след бъбречна трансплантация). Локални фактори, активиращи болестта, са травми- те, болестите на перитонеума, както и хроничните урологични заболявания. ТБК на пикочния мехур е винаги вторична по отношение на увреждането на уретерите.

ТБК зачестява в целия свят, като годишно заболяват 9 милиона нови болни (2). В повечето случаи се стига до оздравяване, но при други се образуват ТБК грануломи, папилит, кавитации, лезии и появата на ТБК бацили в урината. Следват увреждането на уретерите и на пикочния мехур. В малко случаи може да се развие студен абсцес в таза или ингвиналната зона (4), както и туберкулозен остеомиелит.

\section{КЛИНИЧНИ СИМПТОМИ ПРИ ТБК НА УРОГЕНИТАЛНАТА СИСТЕМА:}

Болки в поясната област, дизурия, хематурия. Описват се седем форми на УГТ: хроничен пиелонефрит, хроничен цистит, бъбречна колика, латентна пиурия, безболкова профузна макрохематурия, орхиепидидимит (остра или хронично протичаща форма). По данни на някои автори (1) диагнозата е затруднена в $81 \%$, като е установена до 3 месеца, а в $6 \%$ от болните - доказана до 10 години. В началните форми на УГТБК има умерено изразени дизурични симптоми в резултат на микобактериалните токсини и нервно-циркулаторните им ефекти. Друга проява на болестта е макрохематурията, която възниква внезапно и бързо преминава, тъй като настъпват ерозии в бъбречните папили. Болката е изразена най-вече при отваряне на каверна в бъбрека към уретерите с внезапна хематурия и мъчителна дизурия. Ако каверните имат фистули към кухинната система, болките са слаби, а дизурията е налице. Телесната температура се повишава до 40 градуса, а болката се усилва в съответната област ляв или десен бъбрек. При мъжете едновременното заболяване на бъбреците и епидидима се отчита в $35 \%$. 


\section{ДИАГНОСТИЧНИ МЕТОДИ НА УГ ТБК}

Левкоцитурията е важен лабораторен показател. Тя е значима при 8 и повече левкоцита на поле. Микобактериурията се доказва и при липсата на рентгенови и лабораторни признаци на ТБК. За да бъде резултатът достоверен, броят на ТБК бацилите трябва да бъде между 50000 до 100000 в 1 мл (1). Честотата на културелното доказване на ТБК бактерии варира от 27 до 73\% по метода на Льовенщайн-Йенсен. При 5-кратната посявка на урината за ТБК бактерии за 7 до 10 дни диагнозата се поставя до 70\%. Туберкулиновият тест се отчита до 48 и 72 часа. Болните на хемодиализа имат висок процент на анергия. Изследване за налична ТБК инфекция се прилага с висок процент на точност с квантифероновия тест, с реакцията на верижна полимеризация, както и с Т-клетъчния тест (5).

Изследване на кръвта при УГ ТБК. Хемограмата е в норма само при $37 \%$ от болните. Има моноцитоза - в 17\%, а също и лимфоцитоза (17\%). С-реактивният протеин се повишава при всички форми на УГ ТБК. Доказва се снижение на албумина и повишение на глобулините - алфа- и бета-фракциите, както и повишение на гама-глобулините. Друг метод за доказване активността на УГТ е позитивирането на бласттрансформационния тест, защото пролиферативната активност на лимфоцитите е много изразена. Сега се счита, че методът отпада при наличните бързи методи за доказване на болестта.

\section{- Туберкулинова диагностика}

Пробата на манту се извършва с разтвор на 0,2 мл стар туберкулин на Кох или с пречистен белтъчен дериват (ППД), разреждане 1:1000.

\section{ПАТОГЕНЕЗА}

ТБК инфекция се развива бързо при имуносупресирани болни, включително след бъбречна трансплантация. При първичната ТБК алвеоларните макрофаги са мястото, където вирулентните бацили се размножават с последваща дисеминация в организма (2). Бацилите имат високи изисквания и се размножават в избрана среда, между които и в бъбреците. Възможни други места са простатната жлеза, епидидима, пикочния мехур. При имуносупресирани болни за няколко години се раз- виват туберкули (грануломи) с размери до 3 мм в диаметър. Един или няколко туберкули могат да нараснат за няколко години латентен период - от 5 до 40 години.

\section{БЪБРЕЧНА ТБК С ДРУГИ БЪБРЕЧНИ ЛЕЗИИ}

Има много съобщения за ТБК, съчетана с различни форми на гломерулонефрит, включително милиарна ТБК, усложнена с фокален пролиферативен гломерулонефрит, където се доказват имунни депонирани материи, но без грануломи. Картината на бъбречна ТБК може да се усложни от налични тумори, най-често аденокарциноми, но това е изключително рядко, защото се смята, че туморите могат да активират дремеща ТБК инфекция.

\section{УСЛОЖНЕНИЯ}

Бъбречната ТБК се развива в перинефралната и в ретроперитонеалната област. Фистули могат да се развиват на други места, като стомашно-чревния тракт, кожата, лимфните възли и белите дробове (плевра, бронхи). Описан е случай на бъбречна ТБК, довела до чернодробен абсцес. Хроничната ТБК често се усложнява с амилоидоза, водеща до бъбречна недостатъчност.

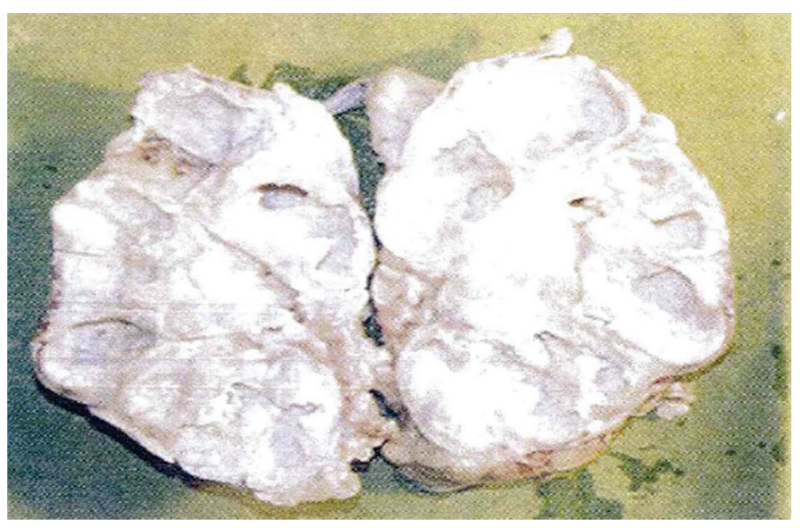

Фиг. 1. Крайна фраза на бъбречно увреждане при УГ ТБК

\section{ОБРАЗНИ ИЗСЛЕДВАНИЯ ПРИ БЪБРЕЧНА ТБК}

Образното представяне на бъбречната ТБК отразява големината на болестния процес. Венозната урография все още се счита за златния стандарт в диагнозата. Има обаче висок риск от алергични реакции и анафилактичен шок при провеждането на този метод. Сега се считат за точни, безопасни и високочувствител- 
ни методите като ултразвуковата ехография, компютърната томография и ядрено-магнитния резонанс (2). Белодробната рентгенография в половината от случаите на УГТ е негативна. В $10 \%$ от това изследване се открива активна ТБК. Описват се извънбелодробни признаци на ТБК, като калцификация на лимфните възли, на надбъбреците, на простатната жлеза, епидидима, псоас абсцеси, вкалцени грануломи в черния дроб и далака, както и аномалии в гръбначния стълб. Фините калцификации, които преди не се визуализираха, могат да се документират сега успешно с компютърна томография (КT).

Ранната калцификация може да бъде аморфна, грануларна или вълнообразна, разположена в бъбречния паренхим. Фокалната глобуларна калцификация с увреждане на един дял често се съчетава с грануломна маса. Пръстеновидните калцификации са типични за папиларната некроза на отделителната система. Калцираната казеозна маса изглежда умерено плътна като матирано стъкло, наричана още „маджунест бъбрек”. Лобарната калцификация с калциеви очертания по периферията на разрушените бъбречни дялове е патогномонична за ТБК. Това се случва в много напреднала бъбречна ТКБ, съчетана с автонефректомия. Калцификацията обхваща и уретера. Всяка калцификация на уретера заедно с друга бъбречна калцификация е признак за бъбречна ТБК. Отчита се, че при $15 \%$ от случаите може да има нормална урография, въпреки налична урогенитална ТБК. Според редица автори ранната папиларна некроза е първият белег на болестта. Наблюдавани са обаче класически форми на форниксна и централна папиларна некроза в сигурни случаи на бъбречна ТБК, които не могат да бъдат разграничени от папиларната некроза при други заболявания. Исхемичната папиларна некроза при бъбречната ТБК се предизвиква от малък гранулом от близките съдове или е резултат от туберкулозен ендартериит.

Установените каликсна дилатация, неясни контури на бъбрека, папиларна некроза и начална кавитация са ранните промени при бъбречната ТБК. Късните са: голяма кавитация, фибротични стриктури, кортикални ръбци, масивни лезии, калцификация, автонефрек- томия, перинефритен абсцес и образуване на фистула.

Кавитация - Ръбцовата деформация на чашките води до прищипване на върха на малките чашки. Продължаващата деструкция води до превръщането на малките калици в огромен джоб с некротична казеозна материя, със или без фиброзна обструкция на инфундибулума.

Стриктури и ръбци - Стриктурите засягат шийката на каликса, инфундибулума или бъбречното легенче, като се последва от хидрокаликс, регионална хидрокаликоза или голямо разширение на чашките и инфундибулума. Така възникват много стриктури, като бъбречното легенче става малко и деформирано.

Обструкцията от стриктури води до дилатация на пиелокаликсната с-ма (ПКС) и до атрофия от притискане на бъбречната тъкан. Възникналата хидронефроза води до неравни граници, показва дефекти при контрастиране, дължащи се на казеозни маси. ТБК инфекцията в дилатираните калици се последва от затворена пиокаликоза и до казеификация на околната тъкан. Напълно стенозиран инфундибулум или каликс води до невъзможност за отделяне на контрастно средство („фантомна чашка").

Ултрасонографията (УСГ), КТ и ядрено-магнитният резонанс (ЯМР) имат значение при диагнозата на болестта с масовите лезии на ТБК грануломи и хидронефрозата, тъй като контрастното вещество не изпълва описаните дефекти. Калцификациите се представят добре с обичайната рентгенография. Отчита се нарастване на бъбречните вкалцявания и на вътрепаренхимните плътни вкалцявания (псевдокалкули).

Автонефректомията е късна фаза на прогресия на грануломатозното бъбречно увреждане с последваща обструктивна уропатия. Съществуват два типа - първият е автонефректомията на казеозно-кавернозния бъбрек, т.е. увеличен бъбрек, превърнат в казеозна торба, а вторият тип - сбръчкан, фибротичен и най-често вкалцен бъбрек. И в двата случая има обструкция на уретера. Нефункциониращи бъбреци при ТБК може да се видят при автонефректомия, обструкция (уретерална обструкция, включително при фиброза след лечение), както и при реноваскулар- 
на хипертония поради увреждане на бъбречната артерия като хипертрофия на медията и склероза на интимата или нейния подлежащ слой. Препоръчва се нефректомия, но винаги следва щателно да се обсъдят рисковете. Ултразвуковата сонография и компютърната томография не само определят нефункциониращия бъбрек, но диагностицират усложненията при болните с бъбречна ТБК (2). Разширението на перинефритните абсцеси до близките тъкани се осъществява чрез синусови ходове или фистули като нефро-гастрична, пиело-дуоденална, бъбречно-дебелочревна и бъбречно-кожна фистула. Описани са също бъбречно-глутеална фистула, както и ингвинална фистула след пробив на студен абсцес. Пиелосинусов или пиелоинтерстициален обратен ток от увреден каликс заедно с обратен пиелолимфен ток е показателен за бъбречна ТБК. „Чуплив каликс" е руптура на форникса, която се вижда при венозната урография (2).

При извършени големи проучвания УСГ доказва диагнозата в 59\% от случаите. Съобща-
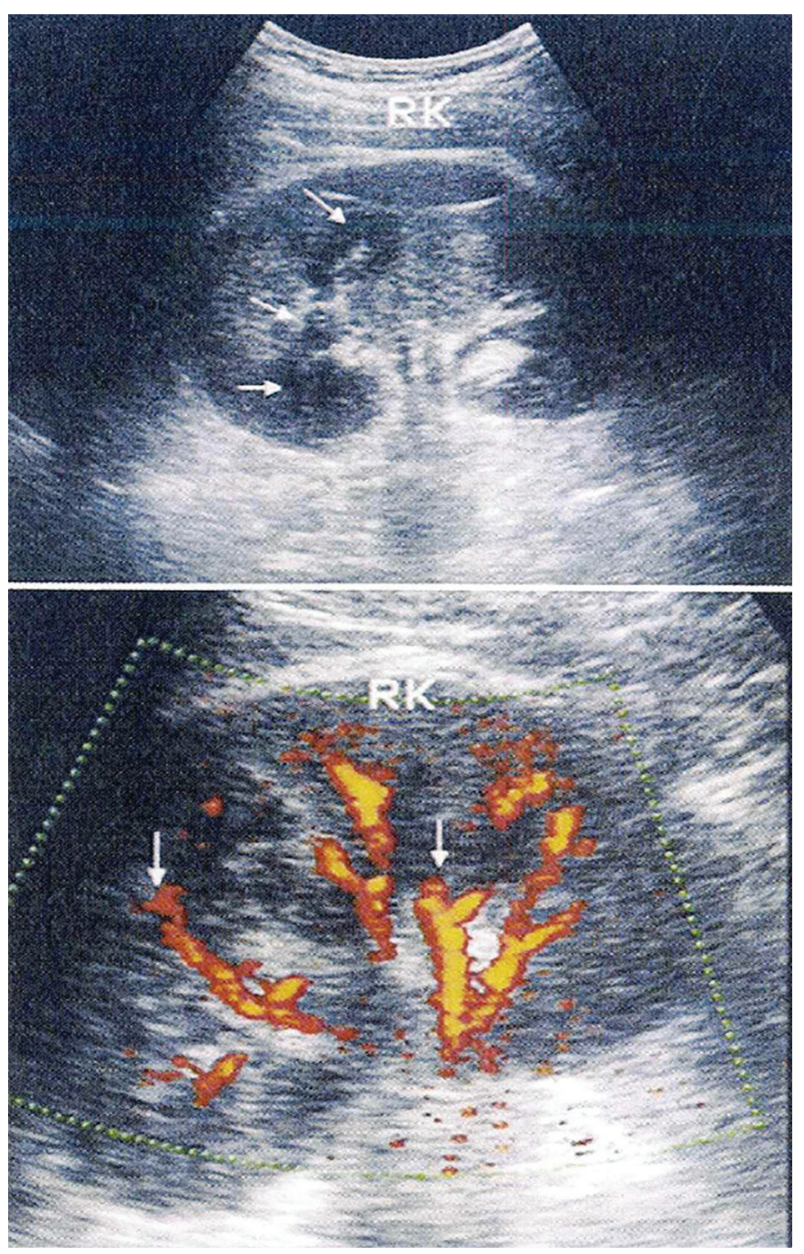

Фиг. 2, 3. Ултразвукова сонография ват се нови данни относно високата ефективност на УСГ чрез използването на високочестотни трансдюсери, което позволява визуализацията на малки начални лезии. Сонографски малките паренхимни промени се представят в размер 5-15 мм с централна зона на ниска ехогенност и ясна външна граница. По-големите фокални лезии се представят със смесена ехогенност и лошо ограничени краища (2). Цветното сканиране дава по-добра видимост при грануломите. Споменава се понятието „лобарна нефрония" в случаите с продължителна температура и болка при негативна посявка за ТБК. Реакцията на верижната полимеризация (polymerase chain reaction, PRU) бързо доказва наличната ТБК. Въведени са нови методи за доказване ТБК, като определяне видово специфичната ДНК, включваща рибозомната РНК, тест за доказване на нуклеинова к-на, генексперт (CVNAAT), GeneXpert - Cepheid USA), Line Probe Assay-LPA - system, T-SPOT - test.

Ултрасонографията - еластография, приложима за тъканен анализ, както и нов метод на акустичния радиационен силов импулс (acoustic radiation force impulse, ARFI)

Разкриват се нови възможности в диагнозата на УГ ТБК. ЯМР и мултидетекторното компютърно томографско сканиране откриват находки в бъбречната патология много по-рано (2). Включват се още спектроскопията и дозираното дифузионно изобразяване. Повечето находки на венозната урография (ВУГ) са достижими чрез високостепенната мултидетекторна КТ, което надхвърля също и данните от ретроградната пиелография.

Ранните промени при бъбречната ТБК се представят с грануломи под и до 3 мм, както и с папиларна некроза. Това може да се постигне с метода на най-новото сканиране с мултидетекторни томографи.

Фибротичните стриктури на инфундибулума и на бъбречното легенче се доказват чрез контрастно представената КТ. Фиброзата резултира в малко - а може и липсващо - бъбречно легенче, което при калцификация се представя като „детелина”. Използва се специално при деца и бременни, когато не трябва да се въздейства с йонизираща радиация. Ефективен е също при болни с хронична бъбречна недостатъчност. Магнитнорезонансна урография, документирана с кинокамера, по- 
казва промените в целия уретер, както и наличието на стенози.

Увреждането на бъбречния паренхим при ТБК винаги въвлича пиелокаликсната система. Използва се още и образно субстракционна система c Gadolinium за доказване на зоните с променена тъканна перфузия. Некротични грануломи се доказват успешно с Т1 и с Т2 импулсни образи.

Дифузионното дозирано представяне чрез ЯМР служи за определяне на бъбречната фиброза. Бъбречната анизотропия се представя добре с новите методи на ядрено-магнитната еластография и на ултразвуковата еластография, както и на комплексните промени в бъбреците при ТБК (2).

Ангиография - Бъбречната ангиография не показва особени промени при бъбречната ТБК. Може да има отклонения в интерлобарните артерии и в аa. arcuatae, както и пълно запушване. Стеснението на вътребъбречните съдове имитира ефекта на компресия от тумори. Намалението на кръвотока около аваскуларна (или хиповаскуларна) зона изключва диагнозата бъбречна ТБК.

\section{ТУБЕРКУЛОЗА ПРИ БЪБРЕЧНА ТРАНСПЛАНТАЦИЯ}

Органната трансплантация е свързана с нарушение в имунитета на пациента. Появата на УГ ТБК най-често е около 6 месеца след трансплантацията. В 18\% от бъбречно трансплантираните се съобщава за поява на бъбречна ТБК. Най-честите усложнения са отхвърляне на бъбрека или смърт на пациента (2). Препоръчва се включването на микофенолат за профилактика на описаната имуносупресия.

\section{ЛЕЧЕНИЕ НА УГ ТБК}

Прилагат се препаратите рифампицин, изониазид, етамбутол, пиразинамид и стрептомицин. Лечението започва с три или четири медикамента за 6 месеца. Според първата схема се включват изониазид, рифампицин, етамбутол или пиразинамид ежедневно за три (3) месеца, след което изониазид и рифампицин два пъти седмично за 3-4 месеца. Втората схема на лечение продължава девет (9) месеца, като първите 3 месеца се започва с рифампицин, изониазид, етамбутол или пиразинамид еже- дневно. Следва приложение на рифампицин и изониазид два пъти седмично за 6 (7) месеца. В много страни се прилага първата схема за лечение на ТБК. Пациентите със СПИН показват резистентност към терапията, поради което приемат етамбутол и изониазид за 18 месеца. Приложените медикаменти се включват в чернодробни метаболитни процеси, а снижението на гломерулната филтрация води до редица токсични прояви. Рифампицинът повлиява обмяната на кортизона и циклоспорина, а изониазидът води до енцефалопатия, поради което се включва пиридоксин 26-50 мг (витамин В 6).

\section{ХИРУРГИЧНО ЛЕЧЕНИЕ}

Инвазивни или хирургични методи се прилагат при хидронефроза и при абсцеси. В този план се включват още реконструкция на уретера, разширение на пикочния мехур, както и операции при генитална ТБК. Операциите са радикални - с отстраняване на все още функциониращия бъбрек, и органосъхраняващи с частична резекция на бъбрека. Всяка оперативна интервенция трябва да се съобразява не само с показанията, но също и с оперативния риск. Необходимо е мотивиране на предоперативната и следоперативната химиотерапия, което значително снижава леталитета.

\section{ПЛАСТИЧНИ ОПЕРАЦИИ}

При множествените стриктури на уретера и периуретрит се прилага чревна пластика на уретера. По данни от редица автори (1) ТБК на пикочния мехур се среща доста често. Хирургичното лечение се нарича сигмоцистопластика, след което се включва и химиотерапия.

\section{ЛИТЕРАТУРА}

1. Камышан, И.С., Погребинский, В.М. Туберкулез мочевых органов, Здоровья, Киев, 1987,3 - 178.

2. Merchant, S., A. Bharati, N. Merchant. Tuberculosis of the genitourinary system: Renal tuberculosis - Part 1. Indian Journal of Radiology and Imaging, 2013, Vol.23,Issue 1, pp.46-63, and Part 2 - Indian J Radiology Imaging, 2013, 23/1/:64 $-77$.

3. Stead, W.W., J.H. Bates. Tuberculosis. EtiologyHarrisons Principles of Internal Medicine, ninth Edition, 1980, p.700.

4. Cumar P., M.Clark, - Tuberculosis. Clinical Medicine, Edition W.B. Saunders, 1998,p. 258. 
5. Streddon,S.,N. Ashman - Renal Tuberculosis. TIN and TB in patients with ESRD. - Oxford Handbook of Nephrology and Hypertension, 2014: 696-699.

6. Daher,E.De fr.,G.B.S.Junior, E.J.G. Borros - Renal Tuberculosis in the Modern Era - The American Journal of Tropical Medicine and Hygiene, 2013, Jan 9: 88/1/ - 54-64.

7. Schaldach, H. Woerterbuch der Medizin, VEB Verlag, Berlin, 1976:518.

8. Stajkova, S., D. Petkova, H. Ganchev, M. Kokoshian, et al. Tuberculosis on transplanted kidney case report. European Respiratory Journal. vol. 24, supp. 48, 2004, 416s.

9. Petkova, D., S. Staykova, H. Ganchev, M. Kokoshian, K. Nenov. Tuberculosis in patients on chronic dialysis and renal transplantation. European Respiratory Journal. vol. 24, supp. 48, 2004, 416s 